\title{
Improving Social Studies Learning Outcomes by Using Learning Video Media For Fourth Grade Students Of SDTQ Al Abidin Surakarta For The 2018/2019 Academic Year
}

\author{
Wiwik Hartatik
}

SDTQ Al Abidin Surakarta

hartatik.wiwik7@gmail.com

\section{Article History}

received 3/12/2020

\begin{abstract}
The research was motivated by the problem of the low social studies learning outcomes of fourth grade students. This is because teachers often use the lecture method, students only listen and record all information from the teacher. This study aims to explain whether the use of instructional video media in social studies subjects for class IV SDTQ Al Abidin Surakarta is able to improve student learning outcomes. This PTK consists of 2 cycles. Data collection techniques from learning outcomes tests at the end of each cycle meeting. The results showed an increase in student learning outcomes for social studies lessons. In the initial conditions, student learning outcomes complete KKM 15\%. In the first cycle, the students who completed the KKM were $50 \%$. The number of students who completed the KKM in the second cycle increased to $85 \%$. There was an increase in the number of students who completed the KKM each cycle. With the evidence in this study, learning with video media is recommended to be applied in learning activities, in an effort to provide quality learning and can improve student learning outcomes.
\end{abstract}

Keywords: learning media, learning videos, learning outcomes

\begin{abstract}
Abstrak
Penelitian dilatarbelakangi oleh permasalahan rendahnya hasil belajar IPS peserta didik kelas IV. Hal ini dikarenakan guru sering menggunakan metode ceramah, peserta didik hanya mendengarkan dan mencatat semua informasi dari guru. Penelitian ini untuk menjelaskan apakah penggunanaan media video pembelajaran pada mata pelajaran IPS kelas IV SDTQ AI Abidin Surakarta mampu meningkatkan hasil belajar siswa. PTK ini terdiri dari 2 siklus. Teknik pengumpulan data dari tes hasil belajar pada setiap akhir pertemuan siklus. Hasil penelitian menunjukkan adanya peningkatan hasil belajar siswa terhadap pelajaran IPS. Pada kondisi awal, hasil belajar siswa tuntas KKM 15\%. Pada siklus I, siswa yang tuntas KKM adalah 50\%. Jumlah siswa yang tuntas KKM pada siklus II meningkat menjadi $85 \%$. Terjadi peningkatan jumlah siswa yang tuntas KKM setiap siklusnya. Dengan adanya pembuktian dalam penelitian ini maka pembelajaran dengan media video direkomendasikan untuk diterapkan dalam kegiatan pembelajaran, dalam upaya memberikan pembelajaran yang berkualitas dan dapat meningkatkan hasil belajar siswa.
\end{abstract}

Kata kunci: media pembelajaran, video pembelajaran, hasil belajar

Social, Humanities, and Education Studies (SHEs): Conference Series https://jurnal.uns.ac.id/shes 


\section{PENDAHULUAN}

Kegiatan pembelajaran di sekolah merupakan kegiatan utama dalam proses pendidikan pada umumnya yang bertujuan membawa peserta didik menuju pada keadaan yang lebih baik. Soemantri (2009: 92) menyatakan Pendidikan IPS adalah penyederhanaan atau adaptasi dari disiplin ilmu-ilmu social dan humaniora, serta kegiatan dasar manusia yang diorganisasikan dan disajikan secara ilmiah dan pedagogis/psikologis untuk tujuan pendidikan. Pada hakikatnya bidang studi IPS merupakan perpaduan pengetahuan sosial. Pelajaran IPS untuk SD merupakan perpaduan ilmu sosial, geografi dan sejarah.

IPS juga membahas antara manusia dengan lingkungannya. Lingkungan masyarakat dimana anak didik tumbuh dan berkembang sebagian dari masyarakat .yang dihadapkan pada berbagai permasalahan yang ada dan terjadi di lingkungan sekitarnya.

Menurut Etin Solihatin dan Raharjo (2007: 15).Tujuan pembelajaran IPS pada dasarnya adalah untuk mendidik dan memberi bekal kemampuan dasar kepada siswa untuk mengembangkan diri sesuai dengan bakat, minat, kemampuan dari lingkungannya serta berbagai bekal bagi siswa untuk melanjutkan ke jenjang pendidikan yang lebih tinggi. Pendidikan IPS berusaha membantu peserta didik dalam memecahkan masalah yang dihadapi sehingga akan menjadikannya semakin mengerti dan memahami lingkungan sosial masyarakatnya

Menurut Dimyati dan Mudjiono (2007: 7) hasil belajar adalah hasil dari suatu interkasi tindak belajar dan tindak mengajar. Hasil belajar ditandai dengan adanya perubahan pada siswa yaitu perubahan tingkah laku, tingkat pengetahuan, dan kemampuan siswa untuk melakukan sesuatu yang berhubungan dengan materi pembelajaran. Sedangkan menurut Slameto (2003: 2) hasil belajar merupakan perubahan yang terjadi dalam diri seseorang yang berlangsung secara berkesinambungan, tidak statis sebagai hasil interaksi dengan lingkungannya. Hasil belajar siswa ditandai dengan adanya perubahan yang lebih baik dalam aspek kemampuan kognitif, afektif dan psikomotor.

Menurut Gagne (dalam Arief S Sadiman, 2012) dengan tanpa menyebutkan jenis dari masing-masing media, pengelompokan media ada tujuh masam yakni benda untuk didemonstrasikan, komunikasi lisan, media cetak, gambar diam, gambar gerak, film bersuara, dan mesin belajar.Media belajar pada dasarnya adalah alat untuk menghindari verbalisme oleh karena itu guru dituntut mampu menyampaikan pesan ajar kepada siswa melalui media dalam bentuk visual maupun audio. Dengan berkembangnya teknologi audio dipertengahan abad ke-20, maka media gambar atau visual juga dilengkapi dengan alat audio untuk lebih mengkongkritkan kegiatan pembelajaran. Alat tersebut lebih dikenal dengan nama media audio visial atau audio visual aids (AVA). Media video merupakan salah satu media audio visual yang menyajikan tampilan gerak dan suara yang sangat menarik. Pesan dari media video bisa bersifat fakta, fiktif, informatif, edukatif, maupun instruksional (Arief S Sadiman, 2012).

Berdasarkan proses pembelajaran sebelum tindakan, nilai ketuntasannya sangat rendah. Dari 20 siswa hanya 3 siswa atau 15\% yang nilainya mencapai KKM dengan rentang nilai $75-90$, sedangkan 17 lainnya atau $85 \%$ mendapatkan nilai dibawah KKM dengan rentang nilai 30-74.

Hal ini dikarenakan saat pembelajaran seringkali dijumpai adanya kecenderungan peserta didik yang malas bertanya kepada guru meskipun sebenarnya mereka belum mengerti tentang materi yang disampaikan oleh guru, masalah ini membuat guru kesulitan dalam menentukan model pembelajaran yang tepat. Mengapa hasil pembelajaran pada mapel IPS masih rendah, peneliti mencoba merefleksi diri tentang proses pembelajaran yang telah berlangsung selama ini. Adapun penyebab dari rendahnya hasil pembelajaran adalah karna tingkat kejenuhan dan kurangnya 
minat peserta didik terhadap pembelajaran IPS. Guru sudah mengajar sesuai dengan standart proses namun masih ada keprihatinan pada saat melakukan proses pembelajaran yaitu, kurangnya kreatifitas dalam menerapkan pembelajaran di kelas, sehingga peserta didik menjadi pasif dan merasa pembelajaran itu menjadi monoton.

Berdasarkan latar belakang tersebut, peneliti merasa perlu melakukan penelitian dengan judul Peningkatan hasil belajar IPS dengan menggunakan media video pembelajaran pada siswa kelas IV SDTQ AI Abidin Surakarta tahun ajaran 2018/2019.

Penelitian ini bertujuan untuk mengukur seberapa jauh penggunaan media video pembelajaran dalam meningkatkan hasil belajar peserta didik kelas IV SDTQ AI Abidin Surakarta dalam mata pelajaran IPS. Selain itu, memberikan penjelasan berdasarkan bukti empiris bahwa medi video pembelajaran mampu meningkatkan Hasil belajar peserta didik kelas IV SDTQ AI Abidin Surakarta dalam mata pelajaran IPS.

\section{METODE}

Jenis penelitian yang dilakukan merupakan Penelitian Tindakan Kelas (PTK) atau Classroom Action Research (CAR). Tindakan tersebut dilakukan oleh guru atau dengan arahan dari guru yang dilakukan oleh peserta didik (Arikunto, 2012:3). Penelitian Tindakan Kelas ini akan dilaksanakan di kelas kelas IV SDTQ AI Abidin Surakarta yang beralamat di Jalan Tarumanegara III Kelurahan Banyuanyar, Kecamatan Banjarsari, Kota Surakarta, Tahun Pelajaran 2018/2019. Penelitian dilaksanakan selama 2 bulan yaitu dari bulan Maret sampai dengan bulan April 2019.

Subyek penelitian yaitu peserta didik kelas IV SDTQ AI Abidin Surakarta yang beralamat di Jalan Tarumanegara III Kelurahan Banyuanyar, Kecamatan Banjarsari, Kota Surakarta. Peserta didik kelas IV SDTQ AI Abidin Surakarta memiliki hasil belajar yang rendah pada mata pelajaran IPS. Peserta didik kelas IV berjumlah 20 peserta didik yang terbagi menjadi 8 peserta didik laki-laki dan 12 peserta didik perempuan.

Penelitian ini menggunakan model Kemmis yang dikembangkan oleh Stephen Kemmis dan Roin Mc Taggart. Model ini meliputi tahapan perencanaan (planning), tindakan (action) dan observasi (observation), dan refleksi (reflection) yang saling terkait satu sama lain. Kemudian diikuti dengan perencanaan ulang yang dilaksanakan dalam bentuk siklus tersendiri (Zainal, 2011:22). Teknik pengumpulan data dilakukan dengan cara observasi (dilakukan selama proses pembelajaran), tes (dilaksanakan pada akhir pembelajaran setiap siklus), dan dokumentasi (melihat situasi pada saat proses pembelajaran) (Sugiyono, 2013: 329).

HASIL DAN PEMBAHASAN

Tabel 1. Presentase Ketuntasan Hasil Belajar IPA Kondisi Awal

\begin{tabular}{ccccc}
\hline \multirow{2}{*}{ No. Nilai } & \multicolumn{2}{c}{ Sebelum Tindakan } & \multirow{2}{*}{ Keterangan } \\
\cline { 3 - 4 } & & Jumlah anak & Presentase (\%) & \\
\hline 1. & $\leq 75$ & 17 & $85 \%$ & Belum Tuntas \\
$2 . \quad \geq 75$ & 3 & $15 \%$ & Tuntas \\
Jumlah & 20 & $100 \%$ & \\
Rata - rata & \multicolumn{3}{c}{55,50} & \\
Nilai Tertinggi & \multicolumn{3}{c}{90} & \\
Nilai Terendah & \multicolumn{3}{c}{30} & \\
\hline
\end{tabular}

Tabel 1 menunjukkan presentase ketuntasan hasil belajar siswa kelas IV SDTQ Al Abidin Surakarta sebelum tindakan, menunjukan bahwa peserta didik yang memperoleh nilai kurang dari KKM 75 sebanyak 17 siswa atau 85\% dari total keseluruhan peserta didik. Sedangkan peserta didik yang nilainya telah mencapai KKM sebanyak 3 siswa atau 15\% dari total keseluruhan siswa. 
Dari hasil tes akhir pada siklus I diperoleh data, dari 20 siswa kelas IV terdapat 10 siswa atau $50 \%$ yang nilainya memenuhi ketuntasan belajar. Sebanyak 10 siswa atau $50 \%$ yang nilainya belum mencapai ketuntasan belajar. Nilai tertinggi yang dicapai siswa adalah 100 sebanyak 2 siswa dan nilai terendah diperoleh 2 siswa juga yaitu 40. Pada siklus I ini rata-rata kelas mencapai 68,50.

Tabel 2. Perbandingan Ketuntasan Hasil Belajar Kondisi Awal dan Siklus I

\begin{tabular}{cccccc}
\hline \multirow{2}{*}{ No. } & \multirow{2}{*}{ Nilai } & $\begin{array}{c}\text { Kondisi awal } \\
\text { anak }\end{array}$ & $\begin{array}{c}\text { Presentase } \\
(\%)\end{array}$ & $\begin{array}{c}\text { Jumlah } \\
\text { anak }\end{array}$ & $\begin{array}{c}\text { Presentase } \\
(\%)\end{array}$ \\
\cline { 3 - 6 } & & 17 & $85 \%$ & 10 & $50 \%$ \\
\hline 1. & Tuntas & 3 & $15 \%$ & 10 & $50 \%$ \\
2. & Belum Tuntas & 20 & $100 \%$ & 20 & $100 \%$ \\
\hline
\end{tabular}

Tabel 2 menunjukkan bahwa terjadi peningkatan jumlah siswa yang tuntas dalam belajar setelah diberikan tindakan pada siklus I. dari kondisi awal ke siklus I mengalami peningkatan ketuntasan belajar yang signifikan, yaitu $15 \%$ menjadi $50 \%$. Selain ketuntasan, rata - rata nilai juga mengalami peningkatan, yaitu dari 55,50 menjadi 68,50 . Pada siklus I ini ketuntasan belajar $50 \%$ berarti peningkatan tersebut belum mencapai kriteria yang diharapkan yaitu $80 \%$ dari total jumlah siswa.

Tabel 3. Perbandingan Hasil Belajar Kondisi Awal, Siklus I dan Siklus II

\begin{tabular}{|c|c|c|c|c|c|c|c|}
\hline \multirow[b]{2}{*}{ No. } & \multirow[b]{2}{*}{ Nilai } & \multicolumn{2}{|c|}{ Kondisi Awal } & \multicolumn{2}{|c|}{ Siklus I } & \multicolumn{2}{|c|}{ Siklus II } \\
\hline & & $\begin{array}{l}\text { Jumlah } \\
\text { anak }\end{array}$ & $\begin{array}{c}\text { Presentase } \\
(\%)\end{array}$ & $\begin{array}{l}\text { Jumlah } \\
\text { anak }\end{array}$ & $\begin{array}{c}\text { Presentase } \\
(\%)\end{array}$ & $\begin{array}{l}\text { Jumlah } \\
\text { anak }\end{array}$ & $\begin{array}{c}\text { Presentase } \\
(\%)\end{array}$ \\
\hline 1. & Tuntas & 3 & $15 \%$ & 10 & $50 \%$ & 17 & $85 \%$ \\
\hline 2. & $\begin{array}{l}\text { Belum } \\
\text { Tuntas }\end{array}$ & 17 & $85 \%$ & 10 & $50 \%$ & 3 & $15 \%$ \\
\hline $\begin{array}{l}\text { Jum } \\
\text { Rata } \\
\text { Nila }\end{array}$ & $\begin{array}{l}\text { rata } \\
\text { rtingqi }\end{array}$ & 20 & $\begin{array}{l}100 \% \\
5,50 \\
90\end{array}$ & 20 & $\begin{array}{l}100 \% \\
68,50 \\
100\end{array}$ & 20 & $\begin{array}{l}100 \% \\
82,50^{100}\end{array}$ \\
\hline
\end{tabular}

Tabel 3 menunjukkan dengan menggunakan media video pembelajaran dapat meningkatkan ketuntasan hasil belajar peserta didik. Pada kondisi awal peserta didik mencapai nilai ketuntasan kriteria minimal $(\mathrm{KKM}=75)$ sebanyak 3 peserta didik dari 20 peserta didik atau $15 \%$. Nilai rata - rata yang diperoleh pada kondisi awal adalah 55,50 dengan pencapaian nilai tertinggi 90 dan terendah 30. Setelah dilakukan tindakan pada siklus I mendapatkan hasil peningkatan yang signifikan, yaitu sebanyak 10 peserta didik telah memperoleh nilai di atas kriteria ketuntasan minimal, jika dalam presentase peserta didik yang telah tuntas sebanyak $50 \%$. Nilai rata - rata yang dicapai juga meningkat menjadi 68,50 dengan pencapaian nilai tertinggi 100 dan terendah 40. Hasil dari penelitian tindakan siklus II juga mengalami peningkatan lagi, dengan ketuntasan belajar menjadi 85\%. Sebanyak 17 peserta didik yang mencapai nilai lebih dari KKM dan 3 peserta didik yang tidak tuntas. Nilai rata - rata yang dicapai setelah siklus II ini juga mengalami peningkatan dari siklus sebelumnya yaitu 68,50 dengan pencapaian nilai tertinggi 100 dan nilai terendah 70 .

Perolehan hasil belajar peserta didik pada siklus I sudah menunjukan adanya peningkatan, dengan ketuntasan klasikal yang mencapai 50\% dan perolehan nilai rata - rata 68,50. Hal ini menunjukan bahwa penelitian tindakan siklus I belum berhasil. Peserta didik yang aktif dalam pembelajaran sudah merata, hanya saja pada awal pertemuan banyak peserta didik yang masih belum aktif dalam mengikuti langkah langkah pembelajaran. Terdapat dua peserta didik yang terlihat belum aktif dalam 
pembelajaran salah satunya disebabkan karena mereka masih merasa takut salah atau malu untuk bertanya, menjawab pertanyaan atau mengemukakan pendapat. Penelitian dilanjutkan ke siklus II dengan memperbaiki dan lebih mengoptimalkan pembelajaran sesuai dengan hasil refleksi. Perbaikan tersebut diantaranya guru lebih memberikan bimbingan kepada peserta didik selama langkah-langkah pembelajaran, peserta didik lebih diarahkan untuk memperhatikan video tersebut, dan guru memberikan reward/penguatan kepada peserta didik yang menjawab dengan benar baik secara individu maupun berpasangan.

Dari pengamatan terhadap proses pembelajaran yang terjadi pada tindakan siklus II, peserta didik menjadi lebih aktif, kreatif dan partisipatif. Peserta didik sudah lebih paham dalam mengikuti langkah-langkah pembelajaran. Hasil ketuntasan belajar dari 20 peserta didik pada siklus II ini meningkat lagi menjadi 85\%. Dapat dikatakan bahwa peserta didik telah mencapai ketuntasan belajar sebab telah memenuhi standart ketuntasan belajar $80 \%$. Sampai pada perbaikan pembelajaran siklus II, ada 17 peserta didik telah mencapai nilai tuntas.

Hasil penelitian tindakan kelas ini, juga sejalan dengan penelitian yang telah dilaksanakan oleh Ana Zuhrotush Sholikhah di MI Negeri Jambu. Ana (2015) menyatakan "terjadi peningkatan hasil belajar siswa dengan menggunakan media video pembelajaran. Pada Siklus II observasi peneliti telah mengalami perubahan dan mencapai taraf persentase yang tinggi. Berdasarkan hasil ini menunjukkan bahwa dengan menggunakan media video pembelajaran hasil belajar siswa pada mata pelajaran IPS kelas IV SDTQ Al Abidin Surakarta meningkat dan berhasil.

Hal yang menjadi persamaan dalam penelitian ini dengan penelitian sebelumnya adalah dilaksanakannya penelitian dengan menggunakan media video pembelajaran. $\mathrm{Hal}$ yang menjadi pembeda dalam penelitian tindakan kelas yang dilaksanakan oleh penulis dengan penelitian terdahulu, adalah mata pelajaran yang digunakan pada penelitian terdahulu adalah IPA sedangkan mata pelajaran yang disampaikan peneliti adalah IPS.

\section{SIMPULAN}

Dalam pembelajaran menggunakan video, peserta didik terlibat lebih aktif dalam mendapatkan informasi. Hal ini menjadikan peserta didik lebih memahami materi, sehingga mampu meningkatnya hasil belajar peserta didik terhadap mata pelajaran IPS. Hasil belajar siswa juga dapat meningkat terbukti dari hasil evaluasi siklus I dan siklus II terdapat peningkatan terhadap hasil belajar peserta didik. Penggunaan media video pembelajaran menjadikan peserta didik belajar secara aktif dan kreatif sehingga dapat meningkatkan hasil belajar kelas IV SDTQ Al Abidin Surakarta, Kecamatan Banjarsari, Kota Surakarta. Oleh sebab itu, penggunaan media video pembelajaran disarankan untuk dapat dikembangkan dan diterapkan dalam pembelajaran yang menyenangkan untuk meningkatkan minat dan hasil belajar peserta didik.

Berdasarkan pembahasan penelitian tindakan kelas yang telah dituliskan, maka dapat dipaparkan implikasi teoritis dan implikasi praktis dari penelitian tindakan kelas ini. Secara teori, implikasi penelitian ini adalah dikembangkannya pembelajaran mata pelajaran IPS dengan menggunakan media video pembelajaran yang menjadikan siswa belajar dengan aktif. Implikasi teoritis dari penelitian ini adalah bertambahnya referensi penelitian dalam bidang pendidikan, pembelajaran menggunakan video pembelajaran lebih baik dari pada model pembelajaran konvesional terlihat dari hasil nilai siswa dan pemahaman terhadap materi yang meningkat.

Implikasi praktis yang diperoleh dari pelaksanaan penelitian tindakan kelas ini adalah sekolah dapat menambah koleksi perpustakaan serta menyediakan referensi bagi guru tentang penelitian tindakan kelas, guru memeroleh pengalaman dalam menerapkan dan mengembangkan pembelajaran dengan media video pembelajaran, dan siswa dapat belajar secara aktif, kreatif dan menyenangkan menggunakan media video untuk meningkatkan kemampuan siswa dalam pelajaran IPS. 


\section{DAFTAR PUSTAKA}

Arikunto, S. (2012). Penelitian Tindakan Kelas. Jakarta: Bumi Aksara

Aqib, Z. (2011). Penelitian Tindakan Kelas. Bandung: Yrama Widya

Dimyati dan Mudjiono. (2002). Belajar dan Pembelajaran. Jakarta: Rineka Cipta.

Hidayati, dkk. (2008). Pengembangan Pendidikan IPS SD. Yogyakarta: Dirjen Pendidikan Tinggi Depdiknas

Sadiman, A. S, dkk, (2012). Media Pendidikan Pengertian, Pengembangan, dan Pemanfaatannya. Pustekom Dikbud dan RajaGrafindo Persada. Jakarta.

Slameto. (2003). Belajar Dan Faktor-Faktor yang Mempengaruhinya. Jakarta: Rineka Cipta.

Soemantri. (2009). Menggagas Pembaharuan Pendidikan IPS. Bandung: PT Remaja Rosdakarya.

Solihatin. E. (2007). Model Pembelajaran IPS. Jakarta: Bumi Akasara.

Sugiyono. (2013). Metode Penelitian Pendidikan. Bandung: Alfabeta

Zuhrotush, A. S. (2015). Penerapan Media Pembelajaran Video dalam Mata Pelajaran IPA di Kelas V MI Negeri Jambu. Malang: Fakultas Teknologi Informasi Universitas Kristen Satya Wacana 